REGARDS

SUR L'ECONOMIE ALLEMANDE

BULLETIN ECONOMIQUE DU CRAC

\section{Regards sur l'économie allemande}

Bulletin économique du CIRAC

$86 \mid 2008$

Varia

\title{
Biographie 2
}

SCHWARZ Hans-Peter, Axel Springer. Die Biografie

\section{(2) OpenEdition}

\section{Journals}

Édition électronique

URL : http://journals.openedition.org/rea/760

DOI : $10.4000 /$ rea. 760

ISBN : 978-2-8218-0868-3

ISSN : 1965-0787

\section{Éditeur}

CIRAC

\section{Édition imprimée}

Date de publication : 1 mai 2008

ISSN : 1156-8992

Référence électronique

"Biographie 2 », Regards sur l'économie allemande [En ligne], 86 | mai 2008, document 2, mis en ligne le 14 mai 2008, consulté le 22 septembre 2020. URL : http://journals.openedition.org/rea/760 ; DOI : https://doi.org/10.4000/rea.760

Ce document a été généré automatiquement le 22 septembre 2020

(c) CIRAC 


\title{
Biographie 2
}

\author{
SCHWARZ Hans-Peter, Axel Springer. Die Biografie
}

\section{RÉFÉRENCE}

SCHWARZ Hans-Peter, Axel Springer. Die Biografie, Propyläen Verlag, Berlin, 2008, $734 \mathrm{p}$.

1 Axel Cäsar Springer (1912-1985) est bien sûr le fondateur du quotidien BILD qui fut à la fois cible et attaquant dans les années d'hystérie allant du mouvement des étudiants au terrorisme (1967-77). Mais dans l'histoire de la presse allemande, ce rénovateur et 'papivore' avait la stature d'un Lazareff et d'un Hersant à la fois. Avec et contre un Rudolf Augstein (fondateur du news magazine Der Spiegel), un John Jahr (éditions Gruner + Jahr) ou un Gerd Bucerius (hebdomadaire Die Zeit), tous basés à Hambourg, il a joué un rôle majeur dans la reconstruction d'une Allemagne démocratique et prospère. Charismatique, commerçant et croyant, conservateur politique et rénovateur de la presse, il a profondément marqué l'histoire de la 'République de Bonn'. Dans deux domaines, son action est peu connue en France: son engagement pour les relations judéo-allemandes et sa vision d'une Allemagne un jour réunifiée qui l'avait amené, peu après la construction du Mur, à transférer le siège de son groupe à Berlin - face au Mur. Voilà enfin une biographie riche et nuancée de cette personnalité toujours idéologiquement controversée, mais qui réunit en elle toutes les contradictions d'une jeune RFA en quête de renouveau. (ib) 